\title{
Knowledge, technique, and taste in transit: diamond polishing in Europe, 1500-1800
}

\section{Karin Hofmeester}

Diamonds were first found, cut and polished, sold and worn in India. Long before 1500 traders from all over the Indian Ocean Sea rim came to India to buy precious stones. While some Indian diamonds reached Europe during the Roman Period, only during the late Middle Ages diamonds made their comeback in Europe. Here, Venice, Antwerp and Amsterdam were the successive 'main centres' of the European diamond trade and polishing industry. ${ }^{1}$ These spatial shifts required a transfer of knowledge and techniques from one place to another which raises the question how knowledge and techniques circulated. Various groups of people played a role in these circulations and each group needed and transferred specific knowledge and skills. For merchants it was vital to know where to buy the right diamonds, how to determine the quality, price and value of rough and polished diamonds, and how to keep track of the taste of consumers. For cutters and polishers it was important to know how to finish the rough stone in the most profitable way: keeping the maximum of weight while giving it the shape that was most in demand. In this article the focus will be on the latter group, but since merchants (often merchant-jewellers) and cutters and polishers were closely interrelated we will also touch upon the sources of knowledge available to merchants.

The basic technique of diamond finishing originated in India, entered Europe some time in the fourteenth century, and remained essentially the same until the introduction of

\footnotetext{
${ }^{1}$ For an overview of these relocations see Karin Hofmeester, "Shifting trajectories of diamond processing: from India to Europe and back, from the fifteenth century to the twentieth, " Journal of Global History 8 (2013), 25-49.
} 
steam and electricity in the nineteenth century. ${ }^{2}$ To prepare a rough diamond for cutting and polishing it had to be roughly shaped or 'bruited'; this could be done by rubbing two diamonds together. The diamond might also be 'cleaved,' if this were required by the shape of the rough stone or by the desired type of cut. This was done with a metal instrument that was inserted in the diamond along the plain of its grain. Finally, if facets had to be applied, the stone was polished with help of a horizontal rotating disk covered with oil and diamond dust. The diamond, set in a holder, was pressed against this rotating disk to polish it facet by facet. ${ }^{3}$ Though size and colour were also important, the differences among polished diamonds lay to a great extent in the way in which they were cut. The development of these cuts show an increasing knowledge of proportions, geometry and refraction, culminating in the prototype of the brilliant cut we know today. This cut was most likely developed in the late seventeenth century and gained popularity in the eighteenth century. Special attention will be paid to this cut as an important example of how innovations in diamond cuts came about and circulated.

2 This point of view is debated and cannot be proven with 'hard evidence.' Godehard Lenzen, The History of Diamond Production and the Diamond Trade (London: Barrie and Jenkins, 1970), 72 and Alois M. Haas, Ludwig Hödel, and Horst Ernst Scheider, Diamant: Zauber und Geschichte eines Wunders der Natur (Berlin: Springer, 2004), 231 all think the origin lies in India. The $14^{\text {th }}$ century Indian gemmology Agastyasamhita described copper polishing wheels, abrasives and bruiting instruments see: S.R. Sarma, 'Historical Notices on Gem Cutting in India," in G. Kuppuram and K. Kumudamani, eds. History of Science and Technology in India vol VI: Metals and Metal Technology (Delhi: Sundeep Prakashan 1990), 141-158, on 149 and 151. Edgar Samuel , "The Invention of Diamond Polishing," Industrial Diamond Review 40 (1980), 5-7.

${ }^{3}$ For a description of the process see Eric Bruton, Diamonds (London: N.A.G. Press, 1970), 180-203. 
In order to answer the question how merchants, jewellers and polishers acquired their experience and how it travelled from one place to another we will look at the possible sources of knowledge. Particular attention will be paid to written sources such as lapidaries, travelogues, and instruction books for merchants, artisans and goldsmiths. But these sources must be understood alongside other factors - especially apprenticeships and guilds--that could stimulate or stymie the circulation of knowledge and skills.

\section{Circulation and innovation}

The background to this circulation was a series of fundamental changes in the cities that dominated the cutting and polishing of diamonds in early modern Europe. Venice was the main European centre for these activities at the start of the early modern period. One of the first documents we have on the polishing industry in Venice is a 1434 regulation of the goldsmith's guild that forbade Jews to trade in precious stones and other lapidaries to teach polishing to Jews. When the guild governors noticed that the trading networks of Jewish merchants were very valuable for the Venetian trade and polishing industry, a 1520 regulation allowed Jews to trade in precious stones but not to polish them. ${ }^{4}$ Despite the regulations, Jews probably found their way in the informal sector of the polishing industry, since a 1639 rule stated that Jews were only allowed to trade in rough stones, not in polished stones. The same regulation complained about the import of polished stones form Ferrara, Mantua and 'foreign cities.' The regulation did not prevent the industry from disappearing: in 1630 Venice

\footnotetext{
${ }^{4}$ Piero Pazzi, I Diamanti nel Commercio nell'Arte e nelle Vicende Storiche di Venezia (Venezia: Monasterio di San Lazzaro degli Armeni, 1986), 13-14.
} 
counted 186 diamond polishing mills and 492 polishers, in 1638 the industry had declined to 22 mills and 47 polishers, and by 1773 only 26 polishers were left. ${ }^{5}$

The first geographical shift in the diamond finishing industry was from Venice to Flanders, first on a small scale in Bruges, later on larger scale in Antwerp. This shift can largely be explained by the rerouting of the diamond trade. ${ }^{6}$ The Portuguese, after their discovery of a sea route to Asia, became the most important rough diamond dealers, largely replacing the trade in Northern Italy. From Lisbon, the Portuguese sent their diamonds to Antwerp, which had become their principal market to sell spices and purchase essentials for the Asian trade and the Iberian economies. ${ }^{7}$ Antwerp now had a structural supply of rough diamonds; it also held a central geographic position, which facilitated service to the European courts. These factors led diamond merchants to settle in Flanders. Initially, in the first half of the sixteenth century, these merchants came from North Italian cities. They included figures such as Giovanni Carlo Affaitadi, of the famous Cremonese family, who made his fortune in the sugar and spice trade and in banking before entering the diamond trade. In the second half of the sixteenth century Portuguese merchants--often New Christians, like the Rodrigues

\footnotetext{
${ }^{5}$ For numbers and regulations see Pazzi 16-17. For the Jews that were caught polishing see Salvatore Ciriacono, "Diamonds in Early Modern Venice: Technology, Products and International Competition," in Ian Pinsker ed., History of Technology, 32 (2014), 67-86, on $76-80$.

${ }^{6}$ For the Bruges trade and industry, see Ludo Vandamme and John A. Rosenhøj, Brugge Diamantstad (Bruges: Vandamme and Rosenhøj cop. 1993).

${ }^{7}$ James C. Boyajian, Portuguese Trade in Asia under the Habsburgs, 1580-1640 (Baltimore, MD: John Hopkins University Press, 1993), 135-136.
} 
d'Evora dynasty--started to play an important role in the diamond trade, profiting from their global trading networks. ${ }^{8}$

Finishing techniques probably moved with the Italian merchants and their artisans from Northern Italy to Flanders. For example, one of Affaitadi's employees was a master diamond cutter named Franz Mesingh, a man of German origin who travelled with the Affatadi's from Piemonte to Flanders. ${ }^{9}$ He cut and polished the stones for the Affaitadi's who then resold them. Also, the Flemish merchant colony in Venice may have helped in transferring the technique. ${ }^{10}$ At the end of the fifteenth century only a handful of diamond finishers lived in Antwerp. Less than a century later, the tax registers for the years 1584-85 included thirty-one diamond cutters and twenty-one diamond polishers. ${ }^{11}$

In Antwerp, knowledge and skills were transferred via apprenticeships. The apprenticeship contracts give us some insights into the learning procedures. These contracts

\footnotetext{
${ }^{8}$ Stadsarchief Antwerpen (henceforth SAA), Notarieel Archief (henceforth NA), N 3624; John Everaert, "Shifting the 'Diamond Connection' Antwerp and the Gem trade with Portuguese India (1590-1636)," in Fátima da Silva Gracias, Celsa Pinto and Charles Borges eds, Indo-Portuguese History: Global Trends. Proceedings of XI-International Seminar on
} Indo-Portuguese History (Goa: Maureen \& Camvet Publishers, 2005), 315-335, on 317-321. 9 Jan Denucé, Inventaire des Affaitadi Banquiers Italiens à Anvers de l'Année 1568 (Antwerpen: Éditions de Sikkel, 1934), 63 and Iris Kockelbergh, Eddy Vleeschdrager, and Jan Walgrave, The Brilliant Story of Antwerp Diamonds (Antwerp: MIM NV, 1992), 41. ${ }^{10}$ Everaert, "Shifting the 'Diamond Connection,"” 321-327, and idem, "Soldaten, Diamantairs en Jezuïeten: Zuid- en Noord-Nederlanders in Portugees-Indië,” in Roelof van Gelder, Jan Parmentier, and Vibeke Roeper, eds. Souffrir pour parvenir: de Wereld van Jan Huygen van Linschoten (Haarlem: Uitgeverij Arcadia, 1998), 80-99 and 182-184, on 89-90.

${ }^{11}$ Kockelbergh, Vleeschdrager and Walgrave, Brilliant Story, 57. 
did not have to be registered before a notary, though many of them were. ${ }^{12}$ The first contract between a master diamond polisher and an apprentice was signed in 1538. That year Joseph Mostaert pledged to learn the trade to Pierre and Anthonie Bacler. Two years later, the same Joseph Mostaert (now mentioned as diamond polisher and merchant in precious stones) taught the trade to Jan van den Broecke, the son of a painter from 's-Hertogenbosch, and to Anthonis van Liesvelt from Dordrecht, in the Northern Netherlands. In 1546 Peter Mostaert taught the trade to the eighteen-year-old Philips Moor from Augsburg. ${ }^{13}$ So knowledge acquired in Antwerp also travelled to other European cities.

In 1582 thirty to forty diamond and ruby cutters in Antwerp received permission from the city council to establish a guild. ${ }^{14}$ The main goal of the guild was to 'protect the quality of the trade.' In practice this meant restricting the status of master to burghers of the city (though foreigners could easily become burghers), limiting the trade to the area within the city walls, introducing an apprenticeship system with long and expensive training, including a master

\footnotetext{
${ }^{12}$ Annelies de Bie, "The Paradox of the Antwerp Rose: Symbol of Decline or Token of Craftmanship," in Karel Davids and Bert de Munck eds, Innovation and Creativity in Late Medieval and Early Modern European Cities (Farnham: Ashgate, 2014), 269-293, on 277. 13 Godelieve van Hemeldonck Leercontracten, Arbeidscontracten en Compagnieën 14141795 (Antwerp, 2008). This very extensive inventory of thousands of apprentice contracts made up with notaries in Antwerp is a wonderful tool to select the diamond polisher's contracts. These particular contracts can be found in SAA N 2070 and N 2073.

${ }^{14}$ Dora Schlugleit, Geschiedenis van het Antwerpsche Diamantslijpersambacht (1582-1797) (Antwerpen: Guillaume, 1935), 9-10.
} 
test, and limiting the number of apprentices per master to three. ${ }^{15}$ The background to these protective measures was perhaps the situation of the industry: by 1584 it was past its peak.

That year, Spanish troops besieged Antwerp; the city surrendered a year later. This brought numerous Portuguese merchants, including diamond dealers and 'their' polishers (often Protestants, perhaps also New Christians) to Amsterdam, both for economic and religious reasons. ${ }^{16}$ In 1589 a diamond cutter (Pieter Goos or Goes, of Antwerp) was for the first time included in an Amsterdam register of intended marriages of the Dutch Reformed Church. ${ }^{17}$ The number of diamond finishers listed in the intended marriage registers in Amsterdam remained small until 1610 (some 25 in total), but then began to increase. Notarial records reveal that the Antwerp immigrants, who formed about $20 \%$ of the diamond cutters noted in the registers, began training others. ${ }^{18}$ In 1612 for example, Andries Pitten from

${ }^{15}$ Schlugleit, Diamantslijpersambacht, 13-18. For a brief peak round 1580 in the increase of new burghers who worked as diamond polishers, see Jan de Meester, "To Kill Two Birds with One Stone: Keeping Immigrants in by Granting Free Burghership in Early Modern Antwerp,” in Karel Davids and Bert de Munck eds, Innovation and Creativity, 95-113 on 103.

${ }^{16}$ Jonathan Israel, “The Economic Contribution of Dutch Sephardi Jewry to Holland's Golden Age, 1595-1713," Tijdschrift voor Geschiedenis, 96 (1983), 505-535, on 508.

${ }^{17}$ Collectie Handschriften Stadsarchief Amsterdam (henceforth SA), 5059/259: Collectie Vaz Dias betreffende joden in Amsterdam. Cahier Diamant I and Schlugleit,

\section{Diamantslijpersambacht, 67.}

${ }^{18}$ The archivist Simon Hart counted all male professions in the registers of intended marriages in Amsterdam for 1600-1715. See SA, Archief Dr S. Hart (henceforth ASH), 883/412-414 and Simon Hart. "Geschrift en Getal. Onderzoek naar de Samenstelling van de Bevolking van Amsterdam in de 17e en 18e eeuw, op grond van Gegevens over Migratie, Huwelijk, Beroep en Alfabetisme," in idem, Geschrift en getal. Een Keur uit de 
Antwerp started to train Samuel Blommaert from London and in 1617 he taught Gerrit Ochehdo from Lisbon. ${ }^{19}$ By 1618 fifty-four polishers were entered in the intended marriage registers and the notarial records. By 1648 there were some $160 .{ }^{20}$

Amsterdam provided diamond merchants an extended financial infrastructure, and the city's supply of rough diamonds increased when the Dutch East India Company (de Verenigde Oostindische Compagnie or VOC) became a successful diamond buyer in India. On top of that, no guild for diamond polishers existed in Amsterdam, so the cutters and finishers were not hindered by guild restrictions and started training new finishers. The consumers of the polished stones remained the various European rulers and the nobility, but now also included a growing bourgeoisie easily reachable from Amsterdam. ${ }^{21}$ In the second half of the seventeenth century the number of diamond cutters and polishers in Amsterdam began to rise. This development is partly explained by the now larger-scale immigration of Portuguese diamond merchants from Antwerp after 1648, in light of the deteriorating economic situation and commencement of a true inquisition against New Christians. ${ }^{22}$ By

demografisch-, economisch- en sociaalhistorische Studiën op grond van Amsterdamse en Zaanse Archivalia, 1600-1800 (Dordrecht: Historische Vereniging Holland, 1976), 115-181. ${ }^{19} \mathrm{SA}, \mathrm{ASH}$, Entries notarial records, 30452/390.

${ }^{20}$ SA, ASH 883/412-414; Archief van S. Hart: (gedeeltelijke) toegang op de notariële archieven 30452/390; Cahier Diamant I Vaz Dias.

${ }^{21}$ Mozes Heiman Gans, Juwelen en mensen. De geschiedenis van het bijou van 1400 tot 1900, voornamelijk naar Nederlandse bronnen (Schiedam: Interbook International, 1979), 76 and 95.

${ }^{22}$ Israel, "Economic Contribution,” 521. 
1748 the number of polishers in Amsterdam was at least $300 .^{23}$ By this point the Amsterdam finishing industry had clearly overtaken Antwerp's, both in terms of volume and the quality of stones processed. ${ }^{24}$

Next to the circulation of knowledge and techniques from one geographical place to another, the innovation of types of cuts is also linked up with an increase of knowledge and techniques from one (type of) workshop to another. The basic shape of the first diamonds mentioned, depicted and inserted in jewellery up until the fifteenth century was the natural eight pointed octahedron, usually named point cut. ${ }^{25}$ It was a small step from the first point cuts to the first table cuts. From 1500 onwards we see table cuts appear in jewellery. Cleaving techniques were needed to shape the table (the flattened top) and faceting was needed to make the crown (which extends from the top of the stone, the table, down to the girdle, the widest part of the diamond). Cleaved off sections of dodecahedral crystals were probably used to make rose cuts. The earliest and simplest rose cuts have no more than three or six facets ground on top and they have a flat bottom. These stones appeared in the sixteenth century and their complexity increased over time. In the late seventeenth century the brilliant cut was

${ }^{23}$ SA: Archieven van de Schout en Schepenen, van de Schepenen en van de Subalterne Rechtbanken, 5061/694, request of a number of non-Jewish diamond cutters to establish a guild.

${ }^{24}$ Henri Heertje, De Diamantbewerkers van Amsterdam (Amsterdam: D.B. Centen's Uitgeverij, 1936), 21.

${ }^{25}$ This description of the diamond cuts is based on Herbert Tillander, Diamond Cuts in Historic Jewellery 1381-1910 (London: Art Books International, 1995), also see Jan Walgrave, "Diamantslijpvormen in de 17e eeuw," in Een Eeuw van Schittering. Diamantjuwelen uit de $17^{e}$ Eeuw (Antwerp: Diamantmuseum, 1993), 37-54, for useful drawings see: http://university.langantiques.com/index.php/A_History_Of_Diamond_Cutting 
developed out of the table cut by adding facets not only to the top of the diamond (the crown) but also to the bottom (the pavilion). The term 'brilliant' refers to the optimal light return in this cut. When light falls onto a transparent gemstone it enters the stone and undergoes refraction. To experience the stone's 'brilliance', light needs to be reflected within the gem so that it leaves the stone in exactly the same the direction from which it came.

Both the quality of the stones and fashion form the background of the development of new types of cut as will be shown by the example of the rose à la mode and the brilliant cut. Antwerp apprenticeship contracts of the second half of the seventeenth century show an increase in detail on the actual cuts to be learned and especially a focus on roses. After 1648, when wealthy Portuguese merchants migrated to Amsterdam, Flemish merchants took over the trade. ${ }^{26}$ Because the best stones were now finished in Amsterdam, Antwerp polishers specialised in cleaving and polishing specific types of roses, especially the rose à la mode, which were very flat and thus could be made from shallow stones. These 'cheaper luxury products' were in vogue, not only in Flanders but also abroad. ${ }^{27}$ Polishers needed special skills to make this new type of cuts and workshops offering this type of knowledge were popular. The rise of the brilliant coincided with the discovery and steady production of diamonds in Brazil in the 1720s. Some experts think that diamonds from specific Brazilian mines had less prismatic colours than the average Indian diamonds ${ }^{28}$, so perhaps something extra was needed to make them glitter while at the same time they were deep enough to make brilliants out of them. Another explanation is that the yield of the Brazilian mines lowered the prices and made diamonds affordable for consumers that had a more fashion determined taste

\footnotetext{
${ }^{26}$ De Bie, “The Paradox of the Antwerp Rose," 275-278; Kockelbergh Vleeschdrager and Walgrave, Brilliant Story, 107, 109 and 119-120.

${ }^{27}$ De Bie, “The Paradox of the Antwerp Rose,” 279-286.

${ }^{28}$ Max Bauer, Precious Stones. Vol 1 (New York: Dover 1986 repr.), 131.
} 
for diamonds: the bourgeoisie who went to fancy candle lit evening parties asked for brilliant jewellery. ${ }^{29}$ Reasons to innovate diamond cuts seem to have been abundant, but who were the innovators and how did the new cuts develop?

It is impossible to pinpoint the actual 'inventors' of specific types of cuts, as Tillander has convincingly shown in the case of the brilliant. ${ }^{30}$ If we assume as he does that new cuts evolved from existing cuts, we have to answer the question in which workshops they were developed. One hypothesis could be that new cuts developed in the workshops working for the court, where diamonds in various shapes were usually available and the appetite for new shapes to distinguish oneself was perhaps larger than in other workshops. According to Tillander, Cardinal Mazarin — the French minister who gave his name to various diamonds and is often mentioned as inventor of the brilliant cut--never invented cuts himself. He was a 'shrewd collector 'of diamonds who accepted the 'most unusual faceting' of eight table cut diamonds, perhaps a 'passing fancy of a craftsman in Paris' and was proud of them. ${ }^{31}$ Could it be that via jewellers - inspired by the above-mentioned new cuts that were also depicted in sketchbooks and engravings - who gave out cutting and polishing orders to the workshops, these innovations may have trickled down to ordinary masters and apprentices? ${ }^{32} \mathrm{We}$ have

${ }^{29}$ Tillander, Diamonds Cuts, 130 and Darcy P. Svisero, James E. Shigley, and Robert Weldon, "Brazilian Diamonds: A Historical and Recent Perspective," Gems \& Gemology. The Quarterly Journal of the Gemological Institute of America 53 (2017), 2-33, 10-11.

${ }^{30}$ Tillander, Diamond Cuts, 130 and 139.

${ }^{31}$ Ibidem, 180.

${ }^{32}$ See Bert De Munck, Technologies of Learning: Apprenticeship in Antwerp Guilds from the $15^{\text {th }}$ Century to the End of the Ancient Régime (Turnhout: Brepols, 2007), 248 on the scholarly discussions about the growing distinction between design and execution, in practice 
very little hard evidence to support this hypothesis though - as we will see - more engravings became available when new types of cutes developed. Since the last quarter of the seventeenth century we see various Antwerp contracts between sons of diamond polishers who go into apprenticeship with other polisher masters, so apparently there was more to learn then they could pick up from their fathers. ${ }^{33}$

\section{Texts on diamonds and their users}

Now we know why main trading and polishing centres relocated, who the prime movers were and which innovations in cutting took place we are in a better position to reconstruct how knowledge and techniques were transferred. Did migrating merchants and their finishers bring their knowledge and skill in their heads and their hands only, or did they also bring documentation? What role was played by sketchbooks, lapidaries, travelogues, and instruction books for merchants, goldsmiths and other artisans? By way of introduction, we have to stress that for the early modern period it is hard to make a distinction between the various genres. For example, lapidaries increasingly overlapped with travelogues. Whereas traditional lapidaries described the healing and other powers of gem stones, Renaissance lapidaries added prices and methods to evaluate gems, information that could be useful for merchants. These lapidaries were often translated from Latin in this period and turned into 'light handbooks in modern European languages,' as Annibale Mottana has described them. ${ }^{34}$ A representative text of this kind, written in Bruges, was Anselmus De Boodt's, Gemmarum et lapidum

between the architect (with his knowledge on mathematics and geometry and drafting) and the artisans. A distinction like this might also have existed in jewelry design and execution.

${ }^{33}$ Van Hemeldonck, Leercontracten, a.o. references to N 485 f 6; N 1620 f-, and N 2512 f-.

${ }^{34}$ Annibale Mottane, "Italian Gemology during the Renaissance: A Step toward Modern Mineralogy," Geologiocal Society of America, Special Paper 411, (2006), 1-21, on 1. 
historia from 1609. ${ }^{35}$ His work was translated into French (1644) as Le parfaict Joallier ou histoire des pierreries and as such probably more accessible for merchants and jewellers. De Boodt was physician at the court of Rudolph II in Prague who had a Kunstkammer with minerals and gemstones. His book is a traditional gemmology that also pays attention to trading and polishing, including extensive tables of the prices of gems and drawings of polishing machines. In principle this treatise could have been used by both merchants and polishers, though Boodt's drawing of a polishing mill that could polish several diamonds simultaneously, invented by himself ( $a$ me inventum est), seems to be an instrument that would never work in practice. ${ }^{36}$ Practically-oriented lapidaries such as Boodt's had much in common with travelogues that described the commodities in newly discovered regions of the globe. Consider, for example, the Italian translation of Duarte Barbosa's accounts of his travels to southern India. These were originally written in Portuguese in 1516 but only became known in 1554 when Giovanni Ramusio summarized them and translated them into Italian; they were also translated into other languages. The book combined data on the natural properties of precious stones with data on the valuation hierarchy of the stones, on weight versus price relationships and other marketing practices. ${ }^{37}$

Not only is it hard to make a distinction between the various sources of knowledge, but the various groups using them sometimes often overlap. One group is the cutters and

\footnotetext{
${ }^{35}$ See the chapters by Bycroft and Rijks in this volume as well as Sven Dupré, "The Art of Glassmaking and the Nature of Stones: The Role of Imitation in Anselm De Boodt's Classification of Stones," in Maurice Sass, Iris Wenderholm and Isabella Augart, eds., Steinformen: Natura - Materia - Artificio (Berlin: De Gruyter, forthcoming)

36 Gemmarum et lapidum-historia: quam olim edidit Anselmus Boetius de Boot 3 ed. (ex officina Ioannis Maire, 1647).

${ }^{37}$ Mottane, "Italian Gemology," 7.
} 
polishers we have already been discussing, the ones that went with the merchants from one city to another and learned the trade from a master. In addition, many merchants were first trained as cutters themselves. We have various examples in Antwerp from masters who became merchants and stopped polishing themselves ${ }^{38}$ Notarial records from Antwerp and Amsterdam show apprenticeship contracts between sons of well-to-do merchants who were trained as diamond polishers; this would point in the direction of a training as cutter as preparation for a merchant career. ${ }^{39}$ A third important group was the highly skilled, well trained jewellers and polishers who worked mostly and sometimes exclusively for the courts. They were the ones who could experiment with large stones, who had the time and the economic freedom to experiment and perhaps also to develop new cuts. ${ }^{40}$ These high-end jewellers and polishers had highly critical consumers and perhaps used sketchbooks to get approval from their customers. ${ }^{41}$ A famous example is the sketchbook made by Arnold Lulls, a Dutch jeweller who moved to London in 1585 and worked for the English court. ${ }^{42}$ These high-end jewellers designed pieces of jewellery but also took care of the production process and hired or commissioned highly skilled polishers who also might have been informed

${ }^{38}$ Schlugleit, Diamantslijpersambacht, 68. This happened especially in the second half of the seventeenth century when part of the polishing moved to Amsterdam and trading remained in Antwerp.

${ }^{39}$ SA, 30452/390 a.o.: NA 3680/241; Van Hemeldonck, Leercontracten, a.o. N65

${ }^{40}$ Louis XIV's court jeweller and polisher Pitau, who worked on a famous blue diamond (later called the Hope diamond) is a good example. See Walgrave, "Diamantslijpvormen in de 17e eeuw,", 51.

${ }^{41}$ I thank Monique Rakhorst for sharing this idea with me.

${ }^{42}$ Gans, Juwelen en mensen, 73-75. 
through these sketchbooks, though the various types of cuts were not always represented in as detailed a manner as possible. ${ }^{43}$

Another example of a sketchbook which did include detailed information on the diamonds used, was made by Thomas Cletscher, a jeweller from The Hague. Between 1625 and 1647 he made drawings from his own jewellery designs but also from other pieces he sold. Probably he made the sketchbook for private and commercial purposes, not to show his patrons or colleagues. ${ }^{44}$ Alongside sketchbooks there are the printed engravings that jewellers such as Gilles Légarés made to advertise their designs.

[Insert figure 1 about here, with the following caption: Figure 1: Eight front and rear sides of jewels designed by Gilles Légarés, from his Livre des Ouvrages d'Orfevrerie engraving by Louis Cossin (Paris, 1663). Collection Rijkmuseum, Amsterdam RP-P-1956437]

Légaré was lodged as jeweller in the Louvre and published the engravings of his designs in 1663. Another example is Friedrich Jacob Morison, a very popular jeweller who worked in Vienna at the end of the seventeenth century. His engravings (published sometime between 1693 and 1697) circulated widely. ${ }^{45}$ New types of cuts may have circulated this way.

\section{Merchants and their possible sources of information}

\footnotetext{
${ }^{43}$ Walgrave, "Diamantslijpvormen," 41-42.

${ }^{44}$ Gans, Juwelen en mensen, 81-95.

${ }^{45}$ For Légaré see Joan Evans, A History of Jewellery 1100-1870 (New York: Dover, 1970 repr.), 145-147. On Morison's work and the circulation of the engravings see Harold Clifford Smith, Jewellery (New York: G. P. Putnam's Sons London: Methuen \& Co, 1908), 309.
} 
As stated above, for merchants it was vital to know where to buy the right diamonds, how to determine the quality and price of rough and polished diamonds and how to keep track of the preferences and taste of consumers. One of the first instructions for merchants can be found in a Hebrew manuscript, dated 1403, on precious stones and their prices in Venice, written by a small-scale Jewish precious stone merchant and jeweller. In 1453 his data were copied by a Jewish jeweller and precious stone merchant from Genoa, who added price data on his city. The original author gave brief descriptions of various precious stones, and prices related to qualities. He also hinted at the source of his knowledge on how to test if a diamond was real: if you look through a polished diamond you see what is quite far in front of you and what is behind you; if you do the same thing with a rough diamond you see part of the stone and part of what is right in front of you. A diamond is very hard and iron cannot touch it, fire cannot darken it. Diamonds attract iron but if you put a needle on it, it will not attract.

'I have heard' is the phrase he used, so perhaps we should also think of the possibility of oral transmission of knowledge. For rough diamonds perfect octahedrons were the best, according to our author, since they could easily be polished. If they were not octahedrons, the buyer had to look twice and buy them as cheap as possible (suggesting that cleaving and cutting these types of stones was still very difficult). The author gave detailed information on the prices paid in Venice of both rough and polished diamonds of various weights. He was well aware of the fact that larger diamonds were relatively more expensive that smaller diamonds: a rough diamond of half carat costed 10 ducats, of one carat 25 ducats, of three carats 150 ducats. Well-polished diamonds were priced accordingly: a diamond of half carat costed 20 ducats, of one carat 60 ducats of three carats 270 ducats and more. Since the Venetian merchant-jeweller also described semi-precious stones and in his detailed price lists focussed on baroque pearls and balas rubies, he might have been a small trader, catering to local bourgeois consumers and 
not to the noblemen or the court. ${ }^{46}$ What the inclusion of his text in the Genova text shows is that apparently also the content of written documents could be transferred from one merchant to the other and that prices and currencies varied in Venice and Genoa.

Specific information on where to sell what in Europe was provided in merchants' handbooks, already in very early ones. In 1503 Bartolomeo di Pasi published his Tariffa de $i$ pesi, e misure corrispondenti dal Levante al Ponente which contained currency, weights and measures and units of other Italian city-states, European neighbours and cities in the Levant, North Africa, the Near and Middle East, including Constantinople, Aleppo, Tripoli, Damascus, Cyprus, Corfu, Rhodes, and Crete. This is clearly a book made for merchants operating on an international scale, if not a global one, from the trading hub that Venice was at the time. Pasi also gave lists of commodities traded between these various places, including diamonds that were mostly coming from Aleppo. He distinguished between diamanti and diamanti in punta. Diamanti in punta were natural octahedrons; they were sent from Venice to Lisbon and Paris. By contrast, diamanti did not have the natural pointed shape and had to be cut and polished into the desired shape; they were sent to Antwerp, where a diamond finishing industry had been developing since the late fifteenth century. ${ }^{47}$

${ }^{46}$ The above information on the Venetian and Genoan manscripts is based on Colette Sirat, “Les Pierres précieuses au XV"e siècle,” Annales, Économies Sociétés Civilisations 23, (1968), 1067-1085, especially 1071, 1078.

${ }^{47}$ Bartolomeo di Pasi, Tariffa de i pesi, e misure corrispondenti dal Levante al Ponente: e da una terra, e luogo allaltro, quasi p tutte le parti dil mondo (Venice: Paolo Gherardo, 1557). The book is not systematically paginated, information can be found under the headings 'Allepo di Soria con Firenza'(165) 'Lisbona di Spagna con Vinetia'; 'Parise di Franza con Vinetia' and 'Vinetia con Anversa di Fiandra' (186). Also see Lenzen, History of Diamond Production, p. 61. 
Travelogues tended to have an even wider geographical scope, and often contained information useful to merchants who went to the Indian mines themselves. Barbosa told his readers where in India the best diamonds could be found, how one could recognize false diamonds (they lost their natural colour), how diamonds were weighed in India (in mangiars), and how they were assigned a price (Barbosa described the same relationship between price and weight as the author of the Hebrew manuscript had described for Venice). ${ }^{48}$ An even clearer example is Jean-Baptiste Tavernier's, Les six voyages de Jean-Baptiste Tavernier (1676). Not only did the author travel very extensively in diamond-producing India and diamond-trading Persia, describing every step in the mining, polishing and trading chain, he also provided information on how to properly value a diamond and determine its price. $\mathrm{He}$ advised the reader to look at the shape, the angles, the clarity (water) and to be aware of points and flaws. If a stone was facetted it should be truly round or oval, well-spread and not lumpy. A stone of good quality of one carat was worth 150 livres; a stone of 12 carat had to be squared and then multiplied by 150 , i.e. the price of one carat. He continued with a set of rules on how to determine the prize of a less-than-perfect diamond. ${ }^{49}$ Tavernier was well informed about the taste of the Indian rulers as he also sold precious stones to them. So here we are informed by a merchant who catered to a truly global group of (often royal) consumers.

Two other texts are worth mentioning as attempts to advise merchants based in Europe on the global market in gems. The first is a merchant's handbook written for the private use of

${ }^{48}$ Original: Duarte Barbosa, Livro de Duarte Barbosa, c 1516, Italian translation 1554, I used the translation made by Mansel Longworth Dames, The Book of Duarte Barbosa (original 1812, repr. New Delhi and Madras: Asian Educational Services, 2002), 221-222. ${ }^{49}$ Jean-Baptiste Tavernier, Travels in India: Translated from the Original French Edition of 1676 by V. Ball vol II (Reprint, New Delhi: Atlantic Publishers \& Distributors, 1989), 74-76. 
the Antwerp-based Colen-De Groot family. Probably written in 1634, this handbook advised that large diamonds over forty carats were far more appreciated in Goa and its surroundings than they were 'here,' meaning Antwerp or perhaps the European market, and should therefore not be sent away. Should any of these large stones reach Antwerp, the book continues, they should be returned to Goa, for they were more expensive 'there' than 'in these countries. ${ }^{50}$ The second text is A Treatise on Diamonds and Pearls, written by the Londonbased jeweller David Jeffries and first published in 1750. The context for this publication was the discovery of diamond mines in Brazil in the late 1720s. Among diamond traders in London, this raised the fear that diamond prices would plummet as they became, in Jeffries' terms, 'as plenty as transparent pebbles.' According to Jeffries, the real problem was the undervaluation of Brazilian diamonds by traders. The solution he proposed in his treatise was to disseminate a new method of evaluating diamonds, boasting that this method was based on 'rules founded on reason and truth' rather than on 'the capricious estimation of unguided judgement.' In fact his method, which was based on the size and quality of diamonds, owed much to earlier methods published by jewellers, especially Tavernier. But Jeffries described the method in great detail and enriched it with comprehensive tables of the prices of diamonds by wright, along with scale drawings of diamonds of different sizes and cuts that readers could use to determine the size, and hence the price, of their own diamonds. Jeffries also gave, for the first time, very detailed information on how to polish a brilliant. As such, his publication was not only a guide for diamond buyers but also for diamond polishers. ${ }^{51}$

${ }^{50}$ Jan Denucé, Koopmansleerboeken van de XVIe en XVIIe Eeuwen in Handschrift (Antwerp: Standaard, 1941), 203-204.

${ }^{51}$ The full title was A Treatise on Diamonds and Pearls, in which their Importance is considered, and Plain rules are exhibited for ascertaining the Value of both, and the True Method of manufacturing Diamonds. I consulted the second edition of 1751. See especially 


\section{Publications from and for court jewellers and their cutters and polishers}

At the end of the sixteenth and the beginning of the seventeenth century a number of books were written by famous goldsmiths who worked for courts and the church, explaining their techniques to a wider audience. Benvenuto Cellini's Trattato dell'Oreficeria, first published in 1568 , described various goldsmithing techniques in extenso, mixing technical descriptions with eloquent biographical remarks. In his introduction he dedicated the printed manuscript to Ferdinando de Medici. According to Paolo L. Rossi, Cellini wrote his treatise to show his possible patrons that he was an artist, an educated gentleman rather than a craftsman, a guild bound goldsmith. ${ }^{52}$ A written version of the manuscript was dedicated to Ferdinando's brother Francesco de Medici. Both brothers were highly interested in goldsmithing, alchemy, mathematics and other technical processes, and Cellini hoped to gain their patronage by providing them the information they were interested in. In his work Cellini gives the first (known) detailed description of the workings of a diamond polishing mill. ${ }^{53}$

pages 65-86 (on Brazilian diamonds) and the tables and diagrams that follow the text. For the information on how to polish brilliants see pages 9-18.

${ }^{52}$ Paolo L. Rossi, “'Parrem uno, e pur saremo dua' The Genesis and Fate of Benvenuto Cellini’s Trattati," in Margaret A. Gallucci and Paolo L. Rossi, Benvenuto Cellini. Sculptor, Goldsmith, Writer (Cambridge: Cambridge University Press 2004), 171-198, on 174.

${ }^{53}$ See for an English translation: The treatises of Benvenuto Cellini on Goldsmithing and Sculpture (Strand: Edward Arnold, 1898). For the description of a diamond polishing mill see pages 31-32. For a digital version of this book see https://archive.org/details/TheTreatisesOfBenvenutoCelliniOnGoldsmithingAndSculpture 
Another very interesting book, less well known nowadays but at least as intriguing, certainly in combination with the author's other work, is Juan de Arphe y Villafañe's, Quilatador de oro, plata y piedras, published in $1572 .{ }^{54}$ De Arphe y Villafañe was a Spanish goldsmith, engraver, sculpture, architect and anatomist. Quilatador is a treatise on assaying precious metals and stones in which the author gives information for other artisans engaged in similar work, information that includes the proper proportion of a rough diamond as well as of a polished table cut diamond, as depicted in figure $2 .{ }^{55}$ Villafañe also informs his reader that colour, clarity and weight together determine the price of a diamond, giving formulae to establish the price of diamonds that were probably followed by Tavernier. ${ }^{56}$

[Insert figure 2 about here, with the following caption: Figure 2: Juan de Arphe y Villafañe, Quilatador de oro, plata y piedras (1562), p. 58. Original: Biblioteca de Castilla y León g-e 732]

As well as this publication, the 'Spanish Cellini' also wrote, between 1585 and 1587, De varia commesuración para la Esculptura y Architectura. This work is divided into four parts. The first part deals with the practice of geometry, the second and third with human and animal proportions, and the fourth with the orders in architecture and proportions in ecclesiastical architecture and silver-work (the latter was his speciality)

\footnotetext{
${ }^{54}$ For a digital version of his book see:

http://fondosdigitales.us.es/fondos/libros/1776/11/quilatador-de-oro-plata-y-piedras/

55 'Juan de Arfe' in Gordon Campbell (ed.), The Grove Encyclopedia of Decorative Arts,

Volume 1 (Oxford: Oxford University Press, 2006), 28.

${ }^{56}$ Lenzen, History of Diamond Production, 95.
} 
[Insert Figure 3 about here, with the following caption: Figure 3: Juan de Arphe y Villafañe, De varia commesuracíon para la Escultura y Architectura (1585-87), p. 19. Original: Biblioteca de Castilla y León g-e 1022]

De Arphe's fascination with proportions led him to carefully describe regular and irregular geometric shapes, including the dodecahedron (the marked shape in Figure 2). This is of course the natural shape of some rough diamonds, and such diamonds are ideal for creating brilliant-cut diamonds. In Figure 3 we see one part of the dodecahedron with six sides, each side subdivided into three, leading to eighteen sides in total. This is far removed from the four-part symmetry we find in the crown of the sixteen facet (taille en seize) predecessors of the brilliant cut. ${ }^{57}$ The alleged link between architecture, geometry and the development of diamond cuts is not new. Herbert Tillander, the authority on the historical development of diamond cuts, suggested that the first table cut diamonds with multiple crown facets (usually sixteen) as depicted by Giles Légaré were based on architectural theory, in this case the Pythagorean diagrams Andrea Palladio depicted in his I Quattri Libri dell'Architectura in $1570 . .^{58}$

[Insert figure 4 about here, with the following caption: Figure 4: detail of a pendant designed by Gilles Légarés, from his Livre des Ouvrages d'Orfevrerie engraving by Louis Cossin (Paris, 1663). Collection Rijkmuseum, Amsterdam RP-P-1956-437]

In the case of De Arphe the two ideas - the ideal proportions in table cut diamonds (written down for the first time $)^{59}$, and the six-part symmetry in the perfect dodecahedron - were

\footnotetext{
${ }^{57}$ Herbert Tillander, Diamond Cuts, 42.

${ }^{58}$ Tillander, Diamond Cuts, 42-43.

${ }^{59}$ Ibidem, 102.
} 
depicted by one artist. Unfortunately we do not know whether he or his readers ever combined the two.

The books by Cellini and De Arphe were written in a period when guilds in Venice tried hard not to disseminate knowledge on their craft outside the circle of guild members. This way of spreading knowledge seemed to be in contradiction to this policy. According to the historian David Humphrey, who described two goldsmithing manuals published in England in 1606 and 1609, these 'revelations' of hitherto 'secret' knowledge can be explained by a number of factors. ${ }^{60}$ First of all, fashion became important, including regular changes in the style and form of jewellery, especially private jewellery. Craftsmen had to inform themselves about these changes. Also, leading goldsmiths had become leading citizens in society, via the guild system and its connections with local government, but also in their relationship with the Crown and the court. They became advisors on the roles of precious objects rather than guardians of the craft and trade. They wanted to show their knowledge to underline their position. ${ }^{61}$ Of the two works analysed by Humphrey, William Heth's The Goulden Arte or The Jewell House of Gemes and H.G.'s [Hannibal Gamon] The Gouldsmythes Storehouse especially the latter contained quite some practical information for diamond polishers on the proportions of a proper table cut diamond, on the way a rough stone should be bought and for which price as well as on the costs of polishing. ${ }^{62}$ For fellow jewellers this must have been a valuable source of information.

\footnotetext{
${ }^{60}$ David Humphrey, “'Hidden Secrets of Ingenious Mistery'. The Curious Nature of Goldsmithing Manuals - Two Tudor-Jacobean Examples," La Revue Société d'Études angloaméricaines des XVIIe et XVIIIe siècles HS 2 (2010), 125-134.

${ }^{61}$ Humphrey, "'Hidden Secrets," 127.

${ }^{62}$ Hazel Forsyth, The Cheapside Hoard. London's Lost Jewels (London: Philip Wilson Publishers, 2014), 77, 154 and 161-163.
} 


\section{Circulation of knowledge through books?}

Many of the texts discussed in the previous section were widely read in Europe. As we have seen, even the very early Hebrew handwritten instructions of the Venetian jeweller circulated and were used fifty years later by a colleague from Genova. Pasi's book was first printed in Venice in 1503 and reprinted 1521; a 1540 edition appears to be the third edition and was followed by another in 1557 . It was a small pocket book, very portable and probably often used by international merchants as it provided them with practical knowledge on and comparisons of weights, and measures used all over Europe, the Middle East and Africa. ${ }^{63}$ The travelogues of Van Linschoten, Duarte Barbosa and Jean-Baptiste Tavernier were translated soon after their publication. Their practical information was used by people like Pieter van Dam, a lawyer to the VOC who was commissioned to compile a guide and reference work on the historical development of the Company. He wrote his work between 1693 and 1701 and included, amongst many other topics, information on the sale of oriental goods in Europe as well as on the development of trade in Asia. Van Dam used various sources he often mentions in the text. ${ }^{64}$ He gives instructions on how to evaluate diamonds by their shape, proportions, and clarity. Most of this type of information was borrowed from the travelogues of Philippus Baldeus, a Dutch minister who went to Ceylon during its Dutch period, and from Jan Huygen van Linschoten. ${ }^{65}$ Part of their information can be traced back to

\footnotetext{
${ }^{63}$ For the use of this book by merchants see Eliyahu Ashtor, Levant Trade in the Middle Ages (Princeton: Princeton University Press, 1983), xxii.

${ }^{64}$ http://resources.huygens.knaw.nl/vocbeschrijvingvandam/index_html_en

${ }^{65}$ Jan Huyghen van Linschoten, Itinerario. Voyage ofte schipvaert [...] naer Oost ofte Portugaels Indien [...]. (Amsterdam: Cornelis Claesz, 1596),104, 106-109. Philippus Baldaeus, Beschryving van het machtige eyland Ceylon ... Nauwkeurige en waarachtige
} 
Duarte Barbosa. Van Dam added data on how to calculate the weight of a diamond once it was polished (by making a lead model) and he added prices of both rough and polished diamonds bought and sold in Amsterdam and Antwerp. ${ }^{66}$ The work was originally intended to be read only by the members of the Company's board, the Gentlemen XVII, but the information in it may have been used by merchants working in the service of the Company.

Taverniers' book was a genuine best-seller. It had twenty-three reprints between its first publication in 1676 and the year 1882. It was subject to ten English translations from 1677 onwards, four German translations from 1681, one Dutch translation in 1662, and one Italian in $1682 .{ }^{67}$ Tavernier's descriptions not only inspired novelists but appeared also in practical publications such as Diderot's Encyclopédie. ${ }^{68}$

Jeffries' book on diamonds and pearls makes it easy to know who read or at least bought his work: it has a preface that lists the subscribers of the book. Many Earls are included, but also three diamond cutters, two jewellers and two goldsmiths. His work, first published in 1750, had a second edition in 1751 and reprints in 1800,1851 and 1871. A

ontdekking en wederlegginge van de afgoderye der Oost-Indische heydenen, Malabaren, Benjanen, Gentiven, Bramines ..., Kustgebieden Malabar Sri Lanka (Amsterdam: Johannes Janssonius van Waesberge\& Joannes van Someren, 1672), 162-164.

${ }^{66}$ Pieter van Dam, Beschrijvinge van de Oostindische Compagnie, book 2, vol II, (The Hague: Martinus Nijhoff, 1932), 181-185, 190-192. The editor of this publication, F.W. Stapel, annotated Van Dam's work and referred to the sources Van Dam used.

${ }^{67}$ Jean-Baptiste Tavernier, Travels in India: Translated from the Original French Edition of 1676 by V. Ball vol I (Reprint, New Delhi: Atlantic Publishers \& Distributors, 1989), 1x-lxvi. ${ }^{68}$ Marcia Pointon, Brilliant Effects: a Cultural History of Gem Stones and Jewellery (New Haven, CT: Yale University Press, 2009), 41. 
French translation was made in 1753. Overall we might conclude that amongst merchants most of the publications mentioned above have circulated, though some more than others.

For the work written by and perhaps also for jewellers/goldsmiths it is more difficult to judge whether this knowledge actually was spread amongst other colleagues. As Rossi's analysis of Cellini's Trattato and Humphrey's analysis of the two British goldsmith manuals show, the purpose of these writings might have been more to strengthen the position of the author-jeweller himself than to spread knowledge on a large scale, though the latter was of course linked to the first. Even so, Rossi lists some fifteen works largely based on the published and unpublished manuscript of the Trattato, all in Italian. ${ }^{69}$ Finally there are the intriguing works by De Arphe y Villafañe. His Quilatador de oro, plata y piedras seems to have undergone two Spanish reprints (in 1598 and 1678) but was not, as far as I know, translated; his geometry De varia commesuración para la Esculptura y Architectura had eight reprints between 1585 and $1806 .{ }^{70}$ Unfortunately we do not know who De Arphe y Villafañe's readers were, nor whether they combined the knowledge of both books.

\section{Sources of knowledge for 'ordinary' master polishers, journeymen and apprentices}

A very important question is how this knowledge reached the 'ordinary' master polishers and the journeymen and apprentices who worked in their workshops. We do know that Hannibal Gamon presented his The Gouldsmythes Storehouse to the Goldsmith Company in 1606, so here it must have been available for his colleagues. ${ }^{71}$ Similarly, an important lapidary by the

\footnotetext{
${ }^{69}$ Rossi, “’Parrem uno, e pur saremo dua,’” 191-192.

${ }^{70}$ Maria Del Carmen Heredia Moreno, “Juan de Arfe Villafañe y Sebastian Serlio,” Archivo Español de Arte, 76 (2003), 371-388, on 372.

${ }^{71}$ Humphrey, “'Hidden Secrets," 128.
} 
French goldsmith Robert Berquen was available for purchase at the headquarters of the Paris guild of goldsmiths after its publication in $1661 .^{72}$ To be able to use these texts masters and apprentices had of course to be able to read. From all 816 notarial deeds made up in Antwerp between 1538 and 1791 that deal with contracts between master diamond polishers and apprentices, three show that the master was not able to write. Though this is a very small part of the total number of masters, it does tell us that even some highly skilled artisans like diamond polishers sometimes were not able to write (though they may have been able to read). Two contracts tell us that the apprentice could not write but would in one case have a chance to learn to do so, which was not an unusual part of the apprenticeship. ${ }^{73}$ Sometimes during guild meetings the agreements were read aloud for apprentices who could not read. ${ }^{74}$ If not every apprentice was able to read at the start of his apprenticeship then at least the basic techniques had to be picked up by learning by doing in the beginning. According to Bert De Munck, in the early modern apprenticeships practical, empirical and specific knowledge was valued over theories. Apprentices learned the technical aspects of the trade on the shop floor, via learning by doing. ${ }^{75}$ If diamond polishers followed this pattern, their apprentices learned in stages and through trial and error, working with real raw diamonds (a practice reflected in

\footnotetext{
${ }^{72}$ Robert de Berquen, Les merveilles des Indes Orientales et Occidentales (Paris, 1661), titlepage.

${ }^{73}$ Van Hemeldonck, Leercontracten. For reading and writing as part of the apprenticeship curriculum see De Munck, Technologies of Learning , 53.

${ }^{74}$ Schlugleit, Diamantslijpersambacht, 171.

${ }^{75}$ Bert De Munck and Hugo Soly, “'Learning on the Shop Floor' in Historical Perspective," in Bert De Munck, Steven L. Kaplan and Hugo Soly eds, Learning on the Shop Floor. Historical Perspectives on Apprenticeships (New York and Oxford: Berghahn Books, 2007), 3-32 on 14-16 and De Munck, Technologies of Learning, 53.
} 
apprenticeship contracts $)^{76}$, experiencing the reaction of the stones to the various production processes, like polishing on a disk, and making a product that had to be sold in the end. According to De Munck, before 1800 books were only used by surgeons and pharmacists who needed examples and recipes. Silversmiths presented apprentices with plates of other works of art to study as examples, and jewellers worked with sheets of models of works of others. ${ }^{77}$ However, from a 1682 probate inventory of a Rotterdam-based silversmith Philip van der Heuvel we know that his son, who started his apprenticeship as silversmith, inherited three books on 'the trade of silversmithing' (unfortunately the titles are not mentioned). The goldsmith and diamond cutter Pieter Quickelenberg of Haarlem, whose probate inventory was made in 1652, also owned books. The titles of these books are unknown, but the fact that they are mentioned immediately after his tools suggests that they were kept in his workshop. ${ }^{78}$ Though these examples are few, they do seem to suggest that even before 1800 books were sometimes used by silversmiths, and perhaps also by diamond polishers, to transmit their knowledge.

\footnotetext{
${ }^{76}$ Sometimes it is stated that the father of the apprentice will deliver the diamonds the apprentice will work on and then provisions on possible loss of the stone are included. Van Hemeldonck, Leercontracten, ref. N 1368 f 22.

${ }^{77}$ De Munck, Technologies of Learning, 53 and 248.

${ }^{78}$ Janneke Tump, Ambachtelijk geschoold. Haarlemse en Rotterdamse ambachtslieden en de circulatie van technische kennis, ca 1400-1720 (Ph D dissertation Vrije Universiteit
} Amsterdam, 2012), 206-207. She also mentions a pattern book found in the workshop of a silversmith. 


\section{Concluding remarks}

As far as sources allow us, we can say that diamond merchants had various sources of knowledge at their disposal that they actually used and probably brought along when they moved from one centre to the other. There were written documents, which were passed on from one jeweller/merchant to the other, as the Venice-Genova manuscript proves. Also, within families handwritten merchant instructions circulated, and were of course also included in correspondence. Finally, knowledge gained from travelogues must have found its way to merchants, either directly--like Tavernier's work--or indirectly, via chroniclers such as Pieter van Dam. Whether merchants actually used practical lapidaries such as Boodt's still has to be proven, even though they were written or translated in European languages.

It is tempting to assume that the highly qualified jewellers working at the courts and probably also their polishers had time and access to rough stones to experiment upon and access to newly printed, written or sketch books with knowledge on various techniques and sciences like mathematics that could lead to innovations in types of cuts. Unfortunately we lack hard evidence to prove this assumption. These books might have been bought by goldsmith guilds for their libraries if they had one; we know that Hannibal Gamon presented his work to the Goldsmith Company. This way master cutters might have had access to them, so further research into this should be helpful. Most apprentices learned by doing on real stones.

What we know for sure is that over time fashion started to play an important role in diamond polishing and in the globalized market each group of consumers had its own preference. There seems to be a link between the quality of available stones on the market and the type of cut a polishing centre specialized in: if lesser quality stones had to be handled, the polishers had to be inventive with new cuts and merchants had to find new niches in the market. 
